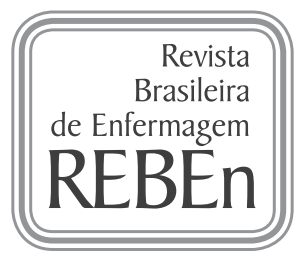

RESEARCH

\title{
Breastfeeding self-efficacy among blind mothers
}

\author{
Autoeficácia em amamentar entre mães cegas \\ Autoeficacia de madres ciegas en la lactancia
}

\section{Sarah Angelo Dias', Thallyta Queiroz Silva', Dyego Oliveira Venâncio', Anne Fayma Lopes Chaves", Ana Carolina Maria Araújo Chagas Costa Lima", Mariana Gonçalves do Oliveira" \\ 'Centro Universitário Estácio do Ceará. Fortaleza, Ceará, Brazil. \\ "Universidade Federal do Ceará. Fortaleza, Ceará, Brazil.}

How to cite this article:

Dias SA, Silva TQ, Venâncio DO, Chaves AFL, Lima ACMACC, Oliveira MG. Breastfeeding self-efficacy among blind mothers. Rev Bras Enferm [Internet]. 2018;71(6):2969-73. DOI: http://dx.doi.org/10.1590/0034-7167-2017-0942

\section{Submission: 02-14-2018Ａpproval: 04-24-2018}

\begin{abstract}
Objective: To evaluate breastfeeding self-efficacy among blind mothers. Method: This is a descriptive and exploratory research carried out in Fortaleza-Ceara, with ten blind mothers. Data were collected through an interview with the application of a socioeconomic and obstetric questionnaire and the Breastfeeding Self-Efficacy Scale - Short Form. Results: The majority of blind mothers presented high breastfeeding self-efficacy, but there were also mothers with low breastfeeding self-efficacy. Conclusion: It is necessary to follow-up mothers throughout the entire breastfeeding period to maintain or improve breastfeeding self-efficacy in this specific public.
\end{abstract}

Descriptors: Breast Feeding; Self Efficacy; Visually Impaired Persons; Maternal-Child Nursing; Weaning.

\section{RESUMO}

Objetivo: Avaliar a autoeficácia em amamentar entre mães cegas. Método: Trata-se de uma pesquisa descritiva e exploratória, realizada em Fortaleza-Ceará, com dez mães cegas. Os dados foram coletados por meio de uma entrevista com a aplicação de questionário socioeconômico e obstétrico e escala Breastfeeding Self - Efficacy Scale - Short Form. Resultados: A maioria das mães cegas apresentou elevada autoeficácia em amamentar, mas também foram evidenciadas mães com baixa autoeficácia em amamentar. Conclusão: Percebe-se a necessidade do acompanhamento das mães durante todo o período da amamentação para buscar manutenção e melhora da autoeficácia em amamentar nesse público específico.

Descritores: Aleitamento Materno; Autoeficácia; Pessoas com Deficiência Visual; Enfermagem Materno-Infantil; Desmame.

\section{RESUMEN}

Objetivo: Evaluar la autoeficacia de madres ciegas en la lactancia. Método: Se trata de una investigación descriptiva y exploratoria realizada en Fortaleza, Ceará, entre diez madres ciegas. Los datos se recogieron mediante entrevistas con la aplicación de un cuestionario socioeconómico y obstétrico y con la versión reducida de la Escala de Autoeficacia para la Lactancia Materna Breastfeeding Self - Efficacy Scale - Short Form. Resultados: La mayoría de las madres ciegas presentaba una autoeficacia elevada en la lactancia, aunque también había algunas con autoeficacia baja. Conclusión: Es evidente que existe una necesidad de seguimiento durante todo el período de amamantamiento para mejorar y mantener la autoeficacia de la lactancia en este público especifico.

Descriptores: Lactancia Materna; Autoeficacia; Personas con Deficiencia Visual; Enfermería Materno-Infantil; Desmame. 


\section{INTRODUÇÃO}

Breastfeeding (BF) is considered one of the fundamental pillars for the promotion and protection of the health of children around the world. The superiority of human milk as food source, protection against diseases and source of affection makes world organizations recommend exclusive breastfeeding for six months of the baby's life and complemented breastfeeding until the second year of life ${ }^{(1)}$.

In spite of these benefits, the rate of exclusive breastfeeding (EBF) is only $41 \%$ in Brazil. Among the Brazilian regions, the Northeast, with only $37 \%$, is the one with the lowest prevalence of EBF in children under six months of age $\mathrm{e}^{(2)}$.

Several factors interfere with the breastfeeding process. Among these, the use of pacifiers and supplements ${ }^{(3)}$, age less than 25 years old ${ }^{(4)}$, level of education ${ }^{(4)}$, low family income ${ }^{(4)}$, low support from health professional ${ }^{(5)}$ and breastfeeding selfefficacy ${ }^{(6)}$. Self-efficacy is highlighted as one of the fundamental concepts and principles of health promotion and is defined as the woman's confidence in her knowledge and skills to successfully breastfeed her child ${ }^{(7)}$. Thus, women need to believe that they can have healthy behaviors so that they can make the efforts necessary to achieve them ${ }^{(8)}$.

For blind mothers, breastfeeding can be a challenge, since simple acts such as bathing, feeding and administering medication become complex, generating stress and insecurity in their child's care ${ }^{(5)}$.

According to the Ministry of Health, the health professional must identify and understand BF in the social, cultural and family context and, from this understanding, take care of the mother/child. It is necessary to find ways to interact with the family, seeking to provide effective, solidary, comprehensive and contextualized assistance, respecting the knowledge and life history of each woman, and helping her overcome fears, difficulties and insecurities ${ }^{(1)}$.

There are currently about 314 million people with visual impairments around the world, of whom 45 million are blind ${ }^{(9)}$. Besides being a significant part of the population, people with visual impairment face several difficulties to exercise their rights in all aspects of life, including health. Some gaps may be highlighted, such as the need for educational material for people with visual impairment, and the development of assistive technologies that facilitate health education ${ }^{(10)}$.

In general, blind parents experience difficulties that are similar to those of sighted parents, but with the addition of insecurity to provide care while deprived of vision and precariousness of the social support network in properly guiding them ${ }^{(11)}$.

Considering the gaps in the literature on BF among blind mothers and knowing the importance of the nursing professional in the care of women in the pregnancy-puerperal cycle, this research will support health professionals, allowing them to know the area in which blind mothers have less confidence, and thus enabling the implementation of strategies for the care and promotion of $\mathrm{BF}$ for this public.

\section{OBJECTIVE}

To evaluate breastfeeding self-efficacy among blind mothers.

\section{METHOD}

\section{Ethical aspects}

Ethical aspects of research involving human beings established by Resolution 466/12 of the Ministry of Health were respected and the study was approved by the Research Ethics Committee of the Federal University of Ceara-COMEPE.

\section{Design, setting and period of study}

This is a descriptive and exploratory research, with quantitative approach, carried out between April and June 2017, in the city of Fortaleza - Ceara.

\section{Population or sample: inclusion and exclusion criteria}

The study population consisted of blind mothers. Ten women were interviewed because the sample was a rare population. The criterion adopted for inclusion in the research was breastfeeding. Women with mental or cognitive impairments that prevented them from responding to the instruments were excluded from the study.

\section{Study protocol}

A non-probabilistic convenience sample was used because the participants were intentionally selected through the snowball technique, in which one participant indicated another and so on. This type of technique is used when it is difficult to find subjects that fit the study.

Data collection was initiated through prior telephone contact with blind women, using the records of a previous research involving this public. The women were invited to participate in the research, and the benefits and purpose of the research were explained. After the acceptance, a face-to-face meeting was held at the participants' home.

The semi-structured interview occurred with the application of a form containing socio-economic data and obstetric history and the Breastfeeding Self - Efficacy Scale - Short Form (BSESSF). The BSES-SF is a self-administered instrument that seeks to measure mothers' self-efficacy in their ability to breastfeed. This scale is composed of 14 items with answers varying from one (1) (totally disagree) to five (totally agree), and women's total scores range from 14 to 70 points.

This scale was developed by a nurse in Canada and translated into several countries, among them Brazi ${ }^{(12)}$. It has also been applied in specific populations and this study is the first to apply it in blind mothers. Even though it is self-administered, the health professional can also apply it, which was the method used in this research.

\section{Analysis of results and statistics}

Statistical analysis was performed in the Epi Info program version 3.5.3. The exploratory analysis of the data consisted of absolute and relative frequencies, means and standard deviations. The self-efficacy of women was classified as follows: low self-efficacy ( 14 to 32 points); medium self-efficacy (33 to 51 points) and high self-efficacy (52 to 70 points).

\section{RESULTS}

The sample consisted of ten blind mothers aged 22 to 43 years old, with a mean age of 35 years old. Seven women had 
congenital blindness and three had acquired blindness. Among the participants, six were married, three were single and one was divorced. Five of the participants were housewives, four were students and one was a domestic secretary.

As for parity, five women were primiparous and five were multiparous. When questioned about previous breastfeeding practice six mothers had not performed it and four had had this experience. All the women performed prenatal care.

The majority of the blind mothers presented high self-efficacy in breastfeeding (seven), with scores between 52 and 70 points. Medium self-efficacy was observed in one mother, with scores ranging from 33 to 51 points and low self-efficacy in two blind mothers, with scores ranging from 14 to 32 points. The items that had higher and lower self-efficacy in breastfeeding are presented in Table 1.

To facilitate the understanding of the analysis of the items, the answers were grouped as follows: "totally disagree" and "disagree" were grouped in "disagree" and "totally agree" and "agree" were grouped in "agree".

The highest-scoring item among women for "agree" was "Deal with the fact that breastfeeding can be time-consuming." However, the lowest score of "disagree" was: "Breastfeed my baby without using formula as a supplement".

Table 1 - Distribution of BSES-SF items according to the responses of the blind mothers

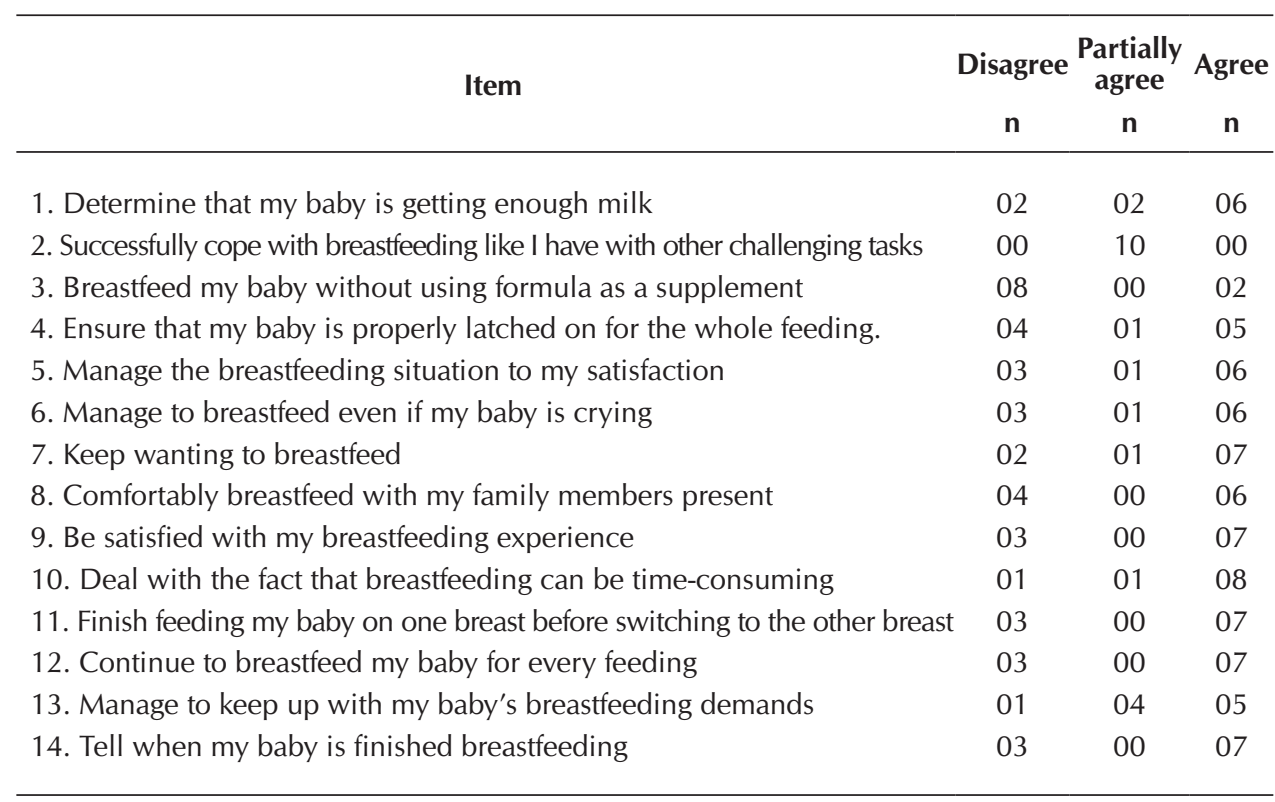

\section{DISCUSSION}

Married mothers or those in a stable union predominated, an aspect that may favor increased breastfeeding self-efficacy ${ }^{(13)}$. Regarding occupation, female housewives prevailed. In the context of breastfeeding, this is considered a protective factor, given that return to work is the main cause of early weaning ${ }^{(14-15)}$.

Regarding parity, there was no difference between the mothers' interviews, as shown in a recent study that evaluated the factors related to breastfeeding self-efficacy among teenagers in the immediate postpartum period. There was no statistically significant association between previous obstetric variables (number of pregnancies, parturitions, abortions and live births) and breastfeeding self-efficacy ${ }^{(16)}$.

A positive finding in this study was that all the participants had prenatal consultations. This fact has great relevance, since recent research involving national and international studies demonstrated that the decision to breastfeed is, in most cases, prior to childbirth ${ }^{(17)}$. Many women report that they have weaned their children for lack of information. Therefore, it is essential to carry out activities to raise awareness and break down taboos ${ }^{(18)}$.

Prenatal care is a fundamental moment to advise mothers about the practice of breastfeeding, since it is a period of close contact between mothers and health professionals, who can guide mothers and encourage them to breastfeed. Nursing professionals stand out as the greatest supporters of this practice ${ }^{(19)}$.

In the present study, a predominance of mothers with high breastfeeding self-efficacy was observed, corroborating a study performed in different regions of Brazil with different audienc$\mathrm{es}^{(20-21)}$. In the context of blind mothers, this finding is considered excellent, since studies indicate that mothers with visual impairment may present greater difficulties to care for their children ${ }^{(5)}$. This finding provides benefits to the practice of breastfeeding, since women with high breastfeeding self-efficacy are more likely to breastfeed for at least six months, so this is a contributing factor for the maintenance of breastfeeding ${ }^{(22)}$.

It is believed that raising awareness among professionals and using educational technologies are factors that favor the mothers' knowledge about $\mathrm{BF}$, making them more confident to breastfeed ${ }^{(23)}$. The importance of the nursing professional must be highlighted, since this professional is responsible for assisting women during the pregnancy-puerperal cycle.

A negative and unprecedented finding of this study was the presence of mothers with low breastfeeding self-efficacy, as no research evaluating maternal self-efficacy had presented this result(20-21). Another factor that may have contributed to this low self-efficacy was primiparity, an aspect that is already evidenced in the literature as a risk factor for low breastfeeding self-efficacy ${ }^{(7)}$.

It is necessary to improve and implement the use of assistive technologies to favor the development of functional ability and enable the performance of the function in which the person is limited due to the disability, thus providing autonomy, quality of life and social inclusion ${ }^{(10)}$. 
Regarding the scale, there was great adherence to the item "Deal with the fact that breastfeeding can be time-consuming". This finding may be associated with the fact that the majority of the women interviewed were housewives. These findings disagree with a research evaluating self-efficacy in teenage mothers, which found greatest adherence in the items: "Ensure that my baby is properly latched on for the whole feeding" and "Tell when my baby is finished breastfeeding"(24).

Corroborating with the findings of another study that applied the BSES-SF to sighted mothers, the item with lower adherence among blind mothers was "Breastfeed my baby without using formula as a supplement"(8). This demonstrates how EBF is still a complex challenge for health professionals, who need to intervene in several factors that lead to early weaning ${ }^{(25-26)}$.

\section{Limitations of the study}

The study had as limitation the reduced number of the sample due to the specific public, which made it not possible to carry out statistical tests to associate the variables with the outcomes.
Contributions to the area of nursing, health or public policies

The present research brought new knowledge related to breastfeeding among a specific public. Interventions related to breastfeeding should be implemented for blind mothers in order to promote breastfeeding, bringing benefits to the mother/child.

\section{CONCLUSION}

Based on the application of the breastfeeding self-efficacy scale it was possible to perceive that blind mothers presented high breastfeeding self-efficacy, a satisfactory finding for the practice of BF. However, there were also mothers with low breastfeeding self-efficacy, a finding not seen in previous studies on this topic.

Knowing that breastfeeding self-efficacy is a changeable aspect, it is necessary to follow up these mothers during the entire period of breastfeeding, so that mothers with high self-efficacy can maintain these levels and mothers with low self-efficacy can improve breastfeeding rates and promote breastfeeding.

\section{REFERENCES}

1. Brasil. Ministério da Saúde. Secretaria de Atenção à Saúde. Departamento de Atenção Básica. Saúde da criança: aleitamento materno e alimentação complementar. Brasília: Ministério da Saúde; 2015.

2. Queluz MC, Pereira MJ, Santos CB, Leite AM, Ricco RG. Prevalence and determinants of exclusive breastfeeding in the city of Serrana, São Paulo, Brazil. Rev Esc Enferm USP[Internet]. 2012[cited 2017 Dec 10];46(3):537-43. Available from: http://www. scielo.br/pdf/reeusp/v46n3/en_02.pdf

3. Costa LKO, Queiroz LLC, Queiroz RCCS, Ribeiro TSF, Fonseca MSS. The importance of exclusive breastfeeding: a systematic literature review. Rev Ciênc Saúde[Internet]. 2013[cited 2017 Dec 21];15(1):39-46. Available from: http://www.periodicoseletronicos.ufma. br/index.php/rcisaude/article/view/1920

4. Esteves TMB, Daumas RP, Oliveira MIC, Andrade CAF, Leite IC. Factors associated to breastfeeding in the first hour of life: systematic review. Rev Saúde Públ[Internet]. 2014[cited 2017 Oct 04];48(4):697-703. Available from: https://www.ncbi.nlm.nih.gov/pmc/ articles/PMC4181097/

5. Wanderley LD, Barbosa GOL, Pagliuca LMF, Oliveira PMP, Almeida PC, Rebouças CBA. Verbal and non-verbal communication of blind mother during child's body hygiene. Rev Rene[Internet]. 2010[cited 2017 Dec 21];11(N-esp):150-9. Available from: http:// www.revistarene.ufc.br/edicaoespecial/a17v11esp_n4.pdf

6. Dennis CL, Heaman M, Mossman M. Psichometric testing of the breasfeeding self-efficacy scale short form among adolescents. J Adolesc Health[Internet]. 2011[cited 2017 Dec 22];49(3):265-71. Available from: https://www.ncbi.nlm.nih.gov/pubmed/21856518

7. Uchôa JL, Gomes ALA, Joventino ES, Oriá MOB, Ximenes LB, Almeida PC. Sociodemographic and obstetric history in maternal self-efficacy in nursing: a study in panel. O Braz J Nurs[Internet]. 2014[cited 2017 Oct 04];13(4):645-55. Available from: http:// www.objnursing.uff.br/index.php/nursing/article/view/4708

8. Rodrigues AP, Padoin SMM, Paula CC, Guido LA. Pre-natal and puerperium factors that interfere on self-efficacy in breastfeeding. Rev Enferm UFPE[Internet]. 2013[cited 2017 Dec 24];7(Esp):4144-52. Available from: http://www.revista.ufpe.br/revistaenfermagem/ index.php/revista/article/download/4031/6314

9. World Health Organization-WHO. World report on diability[Internet]. Geneva; 2011[cited 2017 Dec 24]. Available from: http:// www.who.int/disabilities/world report/2011/en/index.html

10. Barbosa GOL, Wanderley LD, Rebouças CBA, Oliveira PMP, Pagliuca LMF. Development of assistive technology for the visually impaired: use of the male condom. Rev Esc Enferm USP[Internet]. 2013[cited 2017 Oct 23];47(5):1163-9. Available from: http:// www.scielo.br/pdf/reeusp/v47n5/0080-6234-reeusp-47-05-1158.pdf

11. França DNO. The society and sexuality of blind people: prejudice, curiosity, indifference or lack of knowledge?. Rev Latinoam Bioét[Internet]. 2013[cited 2017 Dec 20];13(1):88-95. Available from: http://www.scielo.org.co/pdf/rlb/v13n1/v13n1a09.pdf

12. Dodt RCM. Aplicação e validação da breastfeeding self-efficacy scale-short em puérperas[dissertação]. Fortaleza: Universidade Federal do Ceará; 2008. Available from: http://www.revistarene.ufc.br/revista/index.php/revista/article/view/579/pdf.

13. Dodt RCM, Ximenes LB, Almeida PC, Oriá MOB, Dennis CL. Psychometric and maternal sociodemographic assessment of the 
breastfeeding self-efficacy scale-short form in a Brazilian sample. J Nurs Educ Pract[Internet]. 2012[cited 2017 Oct 04];2(3):67-73. Available from: http://www.sciedu.ca/journal/index.php/jnep/article/view/627/553

14. Rodrigues AP, Padoin SMM, Guido LA, Lopes LFD. Pre-natal and puerperium factors that interfere on self-efficacy in breastfeeding. Esc Anna Nery[Internet]. 2014[cited 2017 Oct 10];18(2):257-61. Available from: http://www.scielo.br/pdf/ean/v18n2/en_14148145-ean-18-02-0257.pdf

15. Margotti E, Epifanio M. Exclusive maternal breastfeeding and the Breastfeeding Self-efficacy Scale. Rev Rene[Internet]. 2014[cited 2017 Oct 04];15(5):771-9. Available from: http://www.revistarene.ufc.br/revista/index.php/revista/article/view/1722/pdf_1

16. Guimarães CMS, Conde RG, Gomes-Sponholz FA, Oriá MOB, Monteiro JCS. Factors related with breastfeeding self-efficacy immediate after birth in puerperal adolescents. Acta Paul Enferm[Internet]. 2017[cited 2018 Jan 15];30(1):109-15. Available from: http://www.scielo.br/pdf/ape/v30n1/1982-0194-ape-30-01-0109.pdf

17. Dodt RCM, Ferreira AMV, Nascimento LA, Macêdo AC, Joventino ES, Ximenes LX. Influence of health education strategy mediated by a self-efficacy breastfeeding serial album. Texto Contexto Enfermagem[Internet]. 2013[cited 2017 Dec 10];22(3):610-8. Available from: http://www.scielo.br/pdf/tce/v22n3/en_v22n3a06.pdf

18. Leal AB, Sousa AF, Florentino EC, Silva LR, Menezes CC. Profile of exclusive breastfeeding and determinants of weaning in a municipality of the semi-arid Northeast of Brazil. Rev Bras Pesqui Saúde[Internet]. 2014[cited 2017 Dec 20];16(3):84-91. Available from: http://periodicos.ufes.br/RBPS/article/view/10155/6896

19. Barbierre CM, Bercini LO, Brondani KJM, Ferrari RAP, Tacla MTGM, Sant'anna FL. Breastfeeding: guidance received in prenatal care, delivery and postpartum care. Semina Cienc Biol Saude[Internet]. 2015[cited 2017 Dec 22];36(1):17-24. Available from: http://www.uel.br/revistas/uel/index.php/seminabio/article/view/16480/16920

20. Soares LS, Machado RS, Rocha SS, Lima LHO, Silva GRF, Oriá MOB. Self-efficacy in nursing donors of human breast milk. Rev Enferm UFPE[Internet]. 2016[cited 2017 Dec 20];10(Supl.2):736-43. Available from: https://periodicos.ufpe.br/revistas/revistaenfermagem/ article/view/11014

21. Souza EFC, Fernandes RAQ. Breastfeeding self-efficacy: a cohort study. Acta Paul Enferm[Internet]. 2014[cited 2017 Dec 15];27(5):46570. Available from: http://www.scielo.br/pdf/ape/v27n5/1982-0194-ape-027-005-0465.pdf

22. Otsuka K, Taguri M, Dennis CL, Wakutani K, Awano M, Yamaguchi, et al. Effectiveness of a Breastfeeding Self-efficacy Intervention: Do Hospital Practices Make a Difference?. Matern Child Health J[Internet]. 2014[cited 2017 Oct 15];18(1):296-306. Available from: https://link.springer.com/article/10.1007/s10995-013-1265-2

23. Oliveira PMP, Pagliuca LMF, Cezario KG, Almeida PC, Beserra GL. Breastfeeding: validation of assistive audio technology for the visually impaired individual. Acta Paul Enferm[Internet]. 2017[cited 2017 Oct 20];30(2):122-8. Available from: http://www.scielo. br/pdf/ape/v30n2/en_1982-0194-ape-30-02-0122.pdf

24. Bizerra RL, Carnaúba JP, Chaves AFL, Rocha RS, Vasconcelos HCA, Oriá MOB. Breastfeeding self-efficacy among adolescents mothers. Rev Eletrôn Enferm[Internet]. 2015[cited 2017 Oct 04];17(3):1-8. Available from: https://www.fen.ufg.br/revista/v17/n3/pdf/v17n3a05.pdf

25. Amaral L, Sales S, Carvalho D, Cruz GKP, Azevedo IC, Ferreira Jr MA. Factors that influence the interruption of exclusive breastfeeding in nursing mothers. Rev Gaúcha Enferm[Internet]. 2015[cited 2017 Oct 10];36(Spe):127-34. Available from: http://www.scielo.br/ pdf/rgenf/v36nspe/en_0102-6933-rgenf-36-spe-0127.pdf

26. Barbosa GEF, Silva VB, Pereira JM, Soares MS, Medeiros Filho RA, Pereira LB, et al. Initial breastfeeding difficulties and association with breast disorders among postpartum women. Rev Paul Pediatr[Internet]. 2017[cited 2017 Dec 10];35(3):265-72. Available from: http://www.scielo.br/pdf/rpp/v35n3/en_0103-0582-rpp-2017-35-3-00004.pdf 